\title{
HOTS Problem Posing on Mathematics Pre-service Teachers
}

\author{
Isnaeni Umi Machromah ${ }^{1}$, Rini Setyaningsih ${ }^{2}$, Christina Kartika Sari $^{3}$, Annisa Swastika ${ }^{4}$, \\ Mufti Khoirunnisa ${ }^{65}$

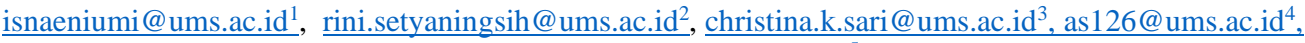 \\ a410170055@student.ums.ac.id ${ }^{5}$ \\ Universitas Muhammadiyah Surakarta ${ }^{1,2,3,4,5}$
}

\begin{abstract}
Higher order thinking skills is one of the most popular issue in Indonesia's education as at this recent time the government made new regulation that learning process should include HOTS concept especially on problem-solving questions. Thus, there are many innovation, implementation, and research related to HOTS problems solving. It is, however, still lack both of implementation and research related to how teacher or preservice teacher could arrange HOTS problems. In this paper, we present new perspective of HOTS problem based on pre-service teacher's ability to design it. The novelty of this perspective is that teacher and pre-service teacher should have ability to pose HOTS problems, while most of research discuss the implementation of HOTS in learning as well its problem solving. This descriptive qualitative research conducted at mathematics preservice teacher joining Assessment and Evaluation of Students Achievement class. Besides, the data was collected by test given for students and validated by researcher triangulation. Then, the data was analyzed by reduction, presentation, and conclusion. The result showed that most of pre-service teacher could not arrange HOTS problems. In fact, their perspective of HOTS problems was wrong. Moreover, 10 pre-service teachers could design HOTS problems with various characteristics
\end{abstract}

Keywords: HOTS, pre-service teacher, problem posing.

\section{Introduction}

Mathematics is one of essential subjects which is taught since elementary school until university. In particular, mathematics in university is unalike mathematics in school as well it is more challenging and abstract. It consists of arithmetic, algebra, geometry, and analysis. In addition, students of faculty teaching and education learn not only pure mathematics but also school mathematics as they are pre-service teachers. Besides, they also study how to teach mathematics for school as well create evaluation instrument for mathematics learning. It is important for pre-service teachers to design a test and non-test assessment as they will use it to evaluate their student's achievement in the future.

In Mathematics Education Department of Universitas Muhammadiyah Surakarta, there is Assessment and Evaluation of Students Achievement subject which aims to introduce students related to learning assessment. In that subject, students were required to arrange a set of instruments that tested in senior high school or vocational school students. Based on that tasks, there were some findings related to how students design a good mathematics question. In particular, there were 16 groups that could arrange a valid mathematics questions, while 4 other groups showed that they were lack of knowledge and understanding related to design good 
mathematics questions. The majority of 16 groups, however, designed questions at the conceptual understanding level which that questions tend to apply a certain formula directly without contextual situation. It means, most of students focused arranging lower order thinking questions. Furthermore, even some students design a contextual mathematics questions, most of them did some mistakes on irrational real situation.

For instance, there is a question related to concept of finding surface area of cube. The question is "There is a beam-shaped hall with a size of 8 meters, 6 meters, and 4 meters. A worker would paint the wall inside of the hall with a cost of Rp 80.000 per square meters. How much the total costs that he needs to paint the wall inside of the hall?'. This question was made by determined the surface area of beam without lid, then the painting costs would be calculated by the result of the surface are multiplication by the costs each square meter. This question is not wrong by the concept. Is that question a contextual problem? however. How could be the hall has the real beam-shaped like a certain beam? At least, it has a door. Therefore, the calculation is not equal to the surface of the beam. Arranging the contextual problems like this need special attention how could students design mathematics contextual problems from the conceptual understanding level to the higher order thinking skills problems. This concept is known as problem posing skill.

Problem posing means asking students to arrange problems or questions based on the certain information provided. Problem posing is an essential aspect especially in learning and teaching mathematics [1]. There are, however, some difficulties on arranging or posing the certain problems for teachers. Based on [2], teachers had some difficulties on posing relevant problems related to real situation that could be understood by students, designing problems that suitable with the applicable curriculum in certain level of education, and also modifying problems that could be understood by their own self. Recently, one of demand both on applicable curriculum and the global issue is how the 21 st century skills could be developed for students both in learning and assessment. Consider to Ravitch, learning by using higher order thinking skills, also known as HOTS, was a complicated and challenging aspect for teacher, especially how could teachers assess students ability with HOTS problems [3].

Based on the previous explanation, problem posing in mathematics learning is one of important aspect both for teachers as well students. Besides, there is a demand for teachers to apply HOTS concept not only for teaching, but also for assessing student's ability included arrange problems with HOTS characteristic. This research aims to identify how pre-service teachers could design HOTS mathematics problems for senior high school students

\section{Related Works}

\subsection{Mathematics Problem Posing}

Mathematics problem posing is student's task that require them to design mathematics problems or questions based on provided information, and also solving the problems that they made directly [4]. Besides, problem posing have relation and benefit for other mathematics skills. Based on [5], learning with problem posing related to indicators of students critical thinking abilities and this abilities could be improved by implementing problem posing concept on learning. Furthermore, problem posing could be enhanced three aspects of creative thinking ability, namely understanding of information, novelty, and fluency, even flexibility aspect did not increase yet [4]. There was a significant relation between problem posing skills and problem 
solving skills [6]. Thus, by giving chance for students for designing their own problems, it would be enhanced their reasoning and reflection skills [1].

There are three ways to find idea on problem posing, namely trial-error, semi-intentional, and intentional [7]. In particular, students ability on problem posing could be analyzed based on five criteria, namely (1) the problems can be solved by students or not; (2) the problems related to the material or provided information or not; (3) solution of the problems are given or not; (4) the problems use correct and good language or not; and (5) level of difficulty [8]. Besides, there is classification of problem solving developing by Afifah [9] based on Siswono and Muiz's criteria. The following Table 1 shows that classification of problem posing.

Table 1. Classification of Problem Posing.

\begin{tabular}{lll}
\hline \multicolumn{1}{c}{ Classification } & Criteria \\
\hline Variety of material & 1. & $\begin{array}{l}\text { Varies: the posing problems consist of more than four different } \\
\text { concepts }\end{array}$ \\
& 2. $\begin{array}{l}\text { Less varied: the posing problems consist of three or four different } \\
\text { concepts }\end{array}$ \\
3. & $\begin{array}{l}\text { Does not vary: the posing problems only consist of one or two } \\
\text { different concepts }\end{array}$ \\
Trend of information & The given information could be grouped as verbal and visual. \\
Problem solving & $\begin{array}{l}\text { 1. The question is clear } \\
\text { 2. }\end{array}$ \\
Level of difficulty & 3. $\begin{array}{l}\text { The quata are enough to answer the questions } \\
\text { problems }\end{array}$ \\
1. $\begin{array}{l}\text { Easy: answer of the problems could be solved by one concept or } \\
\text { formula directly without analyze data to get new information. } \\
\text { Moderate: answer of the problems could be solved by analyze } \\
\text { the data once from the provided information. } \\
\text { c. Hard: answer of the problems could not be solved directly } \\
\text { from the given information and analyze the data more than one } \\
\text { step to solve the problems. }\end{array}$ \\
2.
\end{tabular}

\subsection{Higher Order Thinking Skills (HOTS)}

Thinking is a cognitive proses which explained by various ways. Higher order thinking skills (HOTS) is a concept that use on education reformation based on learning taxonomy such as Bloom's taxonomy. Consider to Crawford \& Smith, the basic idea of HOTS is part of learning which require cognitive knowledge is higher than other knowledge [10]. Moreover, skill of analyzing, evaluating, and creating is needed higher order knowledge compared to remembering facts and concepts, and implementing the concepts. Therefore, HOTS need special strategy on learning problem solving, and also problem posing by higher level questions.

HOTS is one of essential aspect in learning. Based on the research related to pre-service teacher perception about HOTS concluding that students had awareness to the importance of HOTS and learning that focusing on HOTS should be faced as challenge for learning in $21 \mathrm{st}$ century [11]. In addition, HOTS have positive correlation with students achievement in mathematics learning [12]. Besides, HOTS level of students in collage have positive correlation toward their quality of life [13]. 
At least, there are two aspects of HOTS, namely critical thinking ability and creative thinking ability [14]. Moreover, there are three components of HOTS, namely critical thinking ability, creative thinking ability, and also systematic thinking ability [12]. Meanwhile, Consider to Marzano, there are 13 aspect of HOTS, namely comparing, classifying, inductive reasoning, deductive reasoning, analyzing errors, constructing support, analyzing perspectives, abstracting, decision making, investigation, problem solving, experimental inquiry, and invention [15].

\subsection{Related Works}

There was a research conducted by Agustina \& Amin purposing to analyze student's profile of mathematics problem posing in junior high school grade VII [16]. In this research, characteristics of problem posing was analyzed by some criteria, namely students could pose the problems or not; the problems related to the require material or not; students could solve the problems or not; and difficulty level of problems. In particular, the result of that research showed that the boys that have higher ability could design their own mathematics problems; then $92,86 \%$ of students could arrange problems related to the required material; $92,86 \%$ of students could solve their problems correctly; and they arrange easy problems.

From research [9] related to profile of mathematics problem posing on Junior High School students based on cognitive style, showed that student's characteristics with field independent (FI) and field dependent (FD) cognitive style had different type on mathematics problem posing. Students with FI cognitive style had characteristics on problem posing such as the information on problems was verbal; the problem was solvable; there was difficult question, but mostly difficulty level of the questions was moderate; various questions; included new data or information. Meanwhile, students with FD cognitive style had characteristics on problem posing such as there was non-mathematics problems; mathematics problem consist of verbal information; there were some problems that could not be solved; there was difficult problems; the question tended to similar; the problems did not includ new data, in general.

Another research [17] related to students' profile on problem posing based on cognitive style and information categories showed that students with field dependent style could do mathematics problem posing that solvable and includes new data and information; and the problems have high-level quality. Meanwhile students with field dependent style could make problems that solvable, but the problems do not include new data; and the problems have moderate-level quality.

\section{Research Methods}

This research was qualitative description which describe student's problem posing in mathematics for school using HOTS concept. The subject was students of Mathematics Education Department of Universitas Muhammadiyah Surakarta year academic 2017/2018 which had Assessment and Evaluation of Students Achievement class. The data was collected by task that ask students to design mathematics problems with HOTS content. Then, the task was used to identify how students could pose the HOTS problems in mathematics. Besides, the data was analyzed by data reduction, presentation, and conclusion. Moreover, the data was validated by using two researcher which analyze it, namely investigator triangulation. 


\section{Results and Discussion}

Based on the task given for 79 pre-service teachers in mathematics education, all of students could arranging mathematics school problems. However, most of them could not design problems that consist of HOTS content. In particular, less than $20 \%$ of 79 pre-service teachers could arranging mathematics problems with HOTS criteria.

Even only 8 pre-service teachers, they could arrange well mathematics problem posing with HOTS content. At this research, researchers found 2 pre-service teachers design high level of problem posing. Moreover, 3 pre-service teachers made moderate level of HOTS. Meanwhile, only 2 pre-service teachers.

Pak Muslim membeli sekeping tripleks seharga $\mathrm{Rp}$ 125.000. Karena dia minta tripleks tersebut dipotong menjadi 3 bagian yang sama, dia dikenakan biaya Rp 3500 sekali potong. Selanjutnya Pak Muslim harus membayar biaya pengecatan sebesar $30 \%$ dari seluruh biaya setelah pemotongan. Toko memberikan tanda pembayaran sebagai berikut:

1 lembar tripleks@ @ Rp 125000Rp 125.000

3xpemotongan@3500 Rp 10.500+

Subtotal Rp 135.000

Pengecatan Rp 40.650

Total Rp 176.150

Pak Musllim mengatakan biaya tersebut salah. Manakah yang salah?

Fig. 1. Mathematics Problem Solving by Pre-Service Teacher with high HOTS contents.

The first analysis related to characteristic of student's problem posing. Based on Figure 1, it is noticeable that the problem related to given information; it is number material for Junior High School (JHS) grade 7. In particular, the material consists of addition, subtraction, multiplication, division, and percentage in simple calculation. Besides, the problem consists of 3 data analysis to get new information before solving the main problem, namely calculating cost of cutting plywood, calculating cost of painting plywood, and adding up total cost. The main question aims to evaluate the given solution. In addition, given information is interdependent and the problem is solvable. It means that the question-maker had considered whether the problem could be solved or not and the information is enough to solve the problem. Furthermore, the language she used is structured, understandable, and not ambiguous. It shows that the question-maker could use appropriate language based on student level. Additionally, the question tends to use verbal information in short-story form. The question-maker could use real condition or daily activity purposing to make the problem closer to students. This problem has easy level of difficulty since the questions are in basic material. Thus, this problem included on high level of problem posing.

The second analysis related to HOTS characteristics on mathematics problems, consists of Bloom's taxonomy, critical thinking, and creative thinking. Based on Bloom's taxonomy, this 
problem has level C5, evaluation, as the main question of this problem is focusing on how students identify the given solution, find the errors, and do solve the problem correctly. Besides, the problem fulfils enough on categories of critical-thinking problems. The statemen on the problem is clear enough as the reader could directly understand the aims of problems and there is no double meaning of problem. The data are accurate such as the cost of plywood, the cost of cutting and painting also. It shows that the question-maker had done observation related to the real condition. Moreover, the information, data, storyline, and the question are relevance, especially it uses contextual situation and reasonable. Additionally, this problem uses good logical algorithm since the question-maker had presented the solution, and it looks like true, thus the reader should resolve problem by their self. However, this problem has some drawbacks such as the use of unappropriated unit, the deepness and the width of problem.

Furthermore, for creative thinking analysis, this problem fulfils fluency and novelty aspect. As the problem was arranged more than one concept even it was very simple, so this problem has fluency. Besides, this problem quite different with others as the question ask student to evaluate given solution. Thus, students are required to use their critical ability to analyse solution of the problem. Based on the analysis, the problem includes HOTS problem for Junior High School student grade VII.

Pada sebuah kota terdapat dua perusahaan taksi, yaitu Taksi Kenanga dan Taksi

Tulip. Perusahaan tersebut menawarkan tariff seperti pada table berikut.

\begin{tabular}{|l|l|l|}
\hline \multirow{2}{*}{} & \multicolumn{2}{|c|}{ Tarif } \\
\cline { 2 - 3 } & Awal & Per-Km \\
\hline Taksi Kenanga & Rp 6.500,00 & Rp 4.375, 00 \\
\hline Taksi Tulip & Rp 8.000,00 & Rp 4.000,00 \\
\hline
\end{tabular}

Jika kamu ingin bepergian pada jarak $17 \mathrm{~km}$, taksi mana yang kamu pilih?

Mengapa?

Fig. 2. Mathematics Problem Solving by Pre-Service Teacher with high HOTS contents.

Based on Figure 2, it is noticeable that the problem related to given information; it is linear equation material for Junior High School (JHS) grade 7. The problem related to given information; it is linier equation systems material for JHS grade 7. The problem contains 2 data analysis to get new information. Additionally, the main question aims to compare 2 conditions and identify which is the best transportation that will student choose. The information is interdependent and the problem is solvable. The language is structured. It tends to use verbal information. The data are enough to solve the problem. The difficulty level is easy.

Based on Bloom's taxonomy, this problem has level $\mathrm{C} 4$, analysis, as the main question of this problem is focusing on how students comparing two conditions and choosing what is the best answer. Besides, the problem fulfils enough on categories of critical-thinking problems. The statemen on the problem is clear enough as the reader could directly understand the aims of problems and there is no double meaning of problem. The data are quite accurate related to cost of taxi. It shows that the question-maker had done observation related to the real condition. Moreover, the information, data, storyline, and the question are relevance, especially it uses contextual situation and reasonable. Additionally, this problem uses good logical algorithm 
because students should solve two conditions and compare them to get solution. This problem, however, less depth and width as the question is very simple.

For creative thinking analysis, this problem fulfils fluency and novelty aspect. As the problem was arranged more than one concept even it was very simple, so this problem has fluency. Besides, this problem quite different with others as the question ask student to compare two types answer to get best solution. Thus, students are required to use their critical ability to analyse solution of the problem. Based on the analysis, the problem includes HOTS problem for Junior High School student grade VII.

In addition to analysis, this research finds some findings related to how pre-service teachers could make mathematics problems in HOTS level. There are three main findings, namely the problems using real-world situation, the problems related to culture and environment, and the problem using diagram or table or graph to present introductory information.

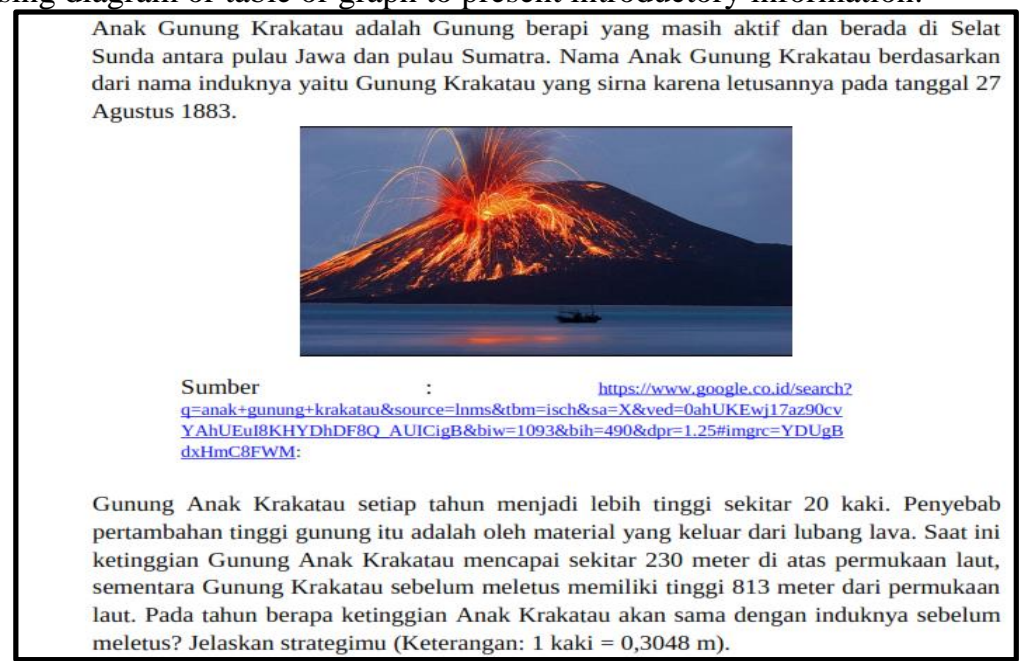

Fig. 3. Findings related to real-world situation.

First findings are related to real-world situation that used by students when creating the problems. Figure 3 is one example showing the problems that use real-world situation, its content is Krakatau mountain. It can be seen that question-maker use real information, real data, and real story about Krakatau mountain. Besides, she also uses both verbal and visual information to construct students' knowledge before facing the main question.

Based on character of problem posing, it can be analysed that the problem is good enough. The problem suitable with the material of sequences and series for Junior High School grade 8. Besides, the problem is solvable; uses appropriate data to solve it; as well the language is structured. The positive side of this problem is using real-world situation, informative stimulus, and verbal as well visual introduction. However, this problem contains only one way of data analysis to solved it.

On the other hand, based on character of critical thinking and creative thinking problem, this problem does not fulfil it as to solve problem it just needs one formula that is very common for students. Moreover, for solving it, students do not need to analyse first. Additionally, even the introduction is very interest and new compared to other problems, but the main question includes routine problem. It also noticeable that the Blooms' taxonomy of this problem has $\mathrm{C} 2$ level, it is explanation. 
Thus, based on the data analysis, this problem is very interested and related to the realworld situation, informative stimulus, also verbal and visual information. This problem, however, does not categorised as HOTS problem as the Blooms' taxonomy in level C2, and does not fulfil critical and creative thinking problems.

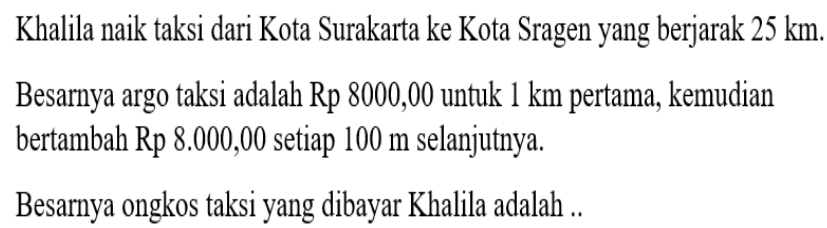

Fig. 4. Findings related to culture and environment.

Second findings are related to culture and environment, means that question-maker use their own culture both local or national, as well as their environment to create or stimulus on mathematics HOTS problem. Figure 4 is one example showing problem using question-makers' environment. It can be seen that question-maker use Surakarta and Sragen city to illustrate the problem. Figure 3 also shows problem that use question-makers' culture as she uses Krakatau mountain which is one of popular mountain in Indonesia. By using culture and environment, student would feel closer with problems and the problem becomes common for students. It would be very different if question-makers use other country culture, students would feel uncommon with problem as the culture are different. Besides, students might not understand with the culture, and it is possible if the culture is contrary to Indonesian culture.

Based on character of problem posing, it can be analysed that the problem is quite good. The problem suitable with the material of linier equation for Junior High School grade 7. Besides, the problem is solvable; uses appropriate data to solve it; as well the language is structured. The positive side of this problem uses contextual problem, and related to questionmaker environment. Meanwhile, the problem includes as routine problem, the stimulus only part of main question, and the problem could be solved without finding new data and only use common formula.

On the other hand, based on character of critical thinking and creative thinking problem, this problem does not fulfil it as to solve problem it just needs one formula that is very common for students. Moreover, for solving it, students do not need to analyse first. Additionally, the problem is arranged by one main concept, one way to solved it, and there is no novelty of the problem. It also noticeable that the Blooms' taxonomy of this problem has $\mathrm{C} 3$ level, it is applying.

Thus, based on the data analysis, this problem is quite interested as it related to the questionmakers' environment. This problem, however, does not categorised as HOTS problem as this problem is routine question, the Blooms' taxonomy in level $\mathrm{C} 3$, and does not fulfil critical and creative thinking problems. 


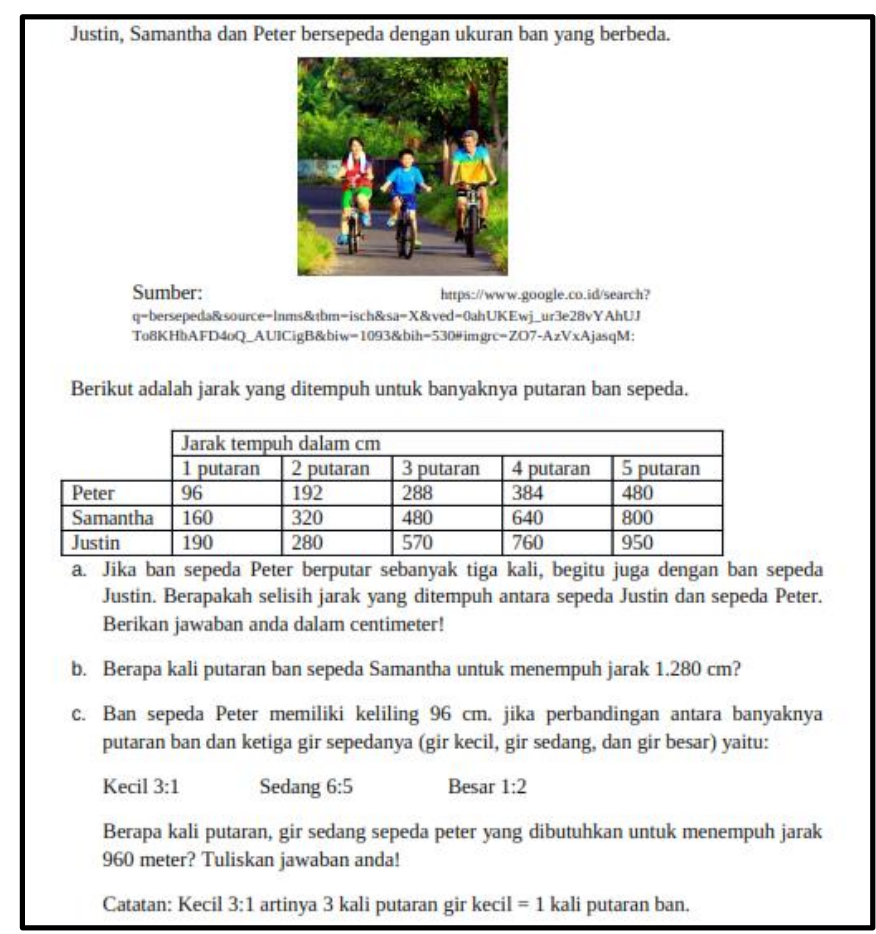

Fig. 5. Findings related to problems' stimulus.

Third findings are related to stimulus that used by question-maker when creating problems. Most of problem use verbal stimulus such as short stories or real-world information. However, another finding is that many pre-service students use diagram, picture, table, and chart to present the information. This is quite unique as they need many appropriate data, then present them to the diagram or table or chart. This activity needs critical and creativity thinking because they have to present in proportional items. Figure 5 is one of the examples that the problem uses both picture and table.

Based on character of problem posing, it can be analysed that the problem is quite good as the question more than one item. The problem suitable with the material of comparation for Junior High School grade 7. Besides, the problem is solvable; uses appropriate data to solve it; as well the language is structured. The positive side of this problem uses data on table to present the information and the problems consist of three questions. Meanwhile, the problem includes as routine problem, each question could be solved by one step, and one question to others are not related each other. So, this problem does not enough to analyse students' ability on higher order thinking.

On the other hand, based on character of critical thinking and creative thinking problem, this problem does not fulfil it as to solve each problem it just needs one step without finding new data. Moreover, for solving it, students do not need to analyse first. Additionally, the problem is arranged by one main concept even it consists of three questions; it is needed only one step to solve it; and there is no novelty of the problem. It also noticeable that the Blooms' taxonomy of this problem has $\mathrm{C} 3$ level, it is applying.

Thus, based on the data analysis, this problem is quite interested as it has been used table to present the data. This problem, however, does not categorised as HOTS problem as this 
problem is routine question, the Blooms' taxonomy in level $\mathrm{C} 3$, and does not fulfil critical and creative thinking problems.

The participants have a high perception in implementing HOTs in the classroom. However, the participants face some difficulties in its implementation, such as time management and students' ability [18]. discovered that preservice teachers would not change their unstated perceptions or beliefs until they saw the difference in teaching and students for themselves [19]. According Hasim, Abdullah, Arifin, \& Noh (2015), the teachers or preservice teacher see that teaching HOTS has future value and this will logically increase their level of commitment and skills that their need in implementing HOTS [20]. we need cultivating a positive awareness of the importance of HOTs in order to fostering the need for teaching that emphasizes the aspects of HOTs during pre-service education [11].

\section{Conclusion}

Pre-service teachers could make mathematics problems for students in elementary, Junior High School, and Senior High School. Most of pre-service teacher, however, still could not design HOTS problems in mathematics. Additionally, pre-service teachers that could design HOTS problems have various characteristics. Some pre-service teachers could design HOTS problems by evaluation the given solution, while others designed HOTS problems by comparing two condition to get the best solution of the problems. Besides, this research also finds three kinds of findings related to the problems that pre-service teachers make. There are three main findings, namely the problems using real-world situation, the problems related to culture and environment, and the problem using diagram or table or graph to present introductory information. For the next research, it is highly recommended to identify how pre-service teachers understand related to HOTS problems as at this research, only some of pre-service teachers that could design HOTS problems in mathematics. Besides, the research could identify pre-service teachers' perspective toward HOTS problems.

\section{References}

[1] I. Lavy and A. Shriki, "Problem Posing As a Means for Developing Mathematical Knowledge of Prospective Teachers," Proc. 31st Conf. Int. Gr. Psychol. Math. Educ., vol. 3, pp. 129-136, 2007.

[2] A. Mallart, V. Font, and J. Diez, "Case Study on Mathematics Pre-service Teachers ' Difficulties in Problem Posing," Eurasia J. Math. Sci. Technol. Educ., vol. 14, no. 4, pp. 1465-1481, 2018.

[3] S. Warner and A. Kaur, "The Perceptions of Teachers and Students on a 21 st Century Mathematics Instructional Model," IEJME - Math. Educ., vol. 12, no. 2, pp. 193-215, 2017.

[4] T. Y. E. Siswono, "UPAYA MENINGKATKAN KEMAMPUAN BERPIKIR KREATIF SISWA MELALUI PENGAJUAN MASALAH 1 Tatag Yuli Eko Siswono Jurusan Matematika FMIPA Unesa," J. Pendidik. Mat. dan Sains, vol. X, no. 1, pp. 1-15, 2005.

[5] N. W. Shanti, D. A. Sholihah, and A. Martyanti, "Meningkatkan Kemampuan Berpikir Kritis melalui Problem Posing," LITERASI, vol. VIII, no. 1, pp. 49-59, 2017.

[6] T. Kar, E. Özdemir, A. S. Ipek, and M. Albayrak, "The relation between the problem posing and problem solving skills of prospective elementary mathematics teachers," Procedia - Soc. Behav. Sci., vol. 2, no. 2, pp. 1577-1583, 2010.

[7] E. Patakova, "Teachers' problem posing in mathematics," Procedia - Soc. Behav. Sci., vol. 93, pp. 836-841, 2013.

[8] E. Yudianto, "Profil Pengajuan Soal Mahasiswa Calon Guru Berkemampuan Rendah," 
AdMathEdu, vol. 2, no. 1, pp. 1-10, 2012.

[9] D. S. N. Afifah, "PROFIL PENGAJUAN MASALAH MATEMATIKA SISWA SMP BERDASARKAN GAYA KOGNITIF,” J. Pendidik. dan Pembelajaran Mat., vol. 1, no. 1, pp. 100-111, 2015.

[10] D. Sulisworo, "Mobile Learning Application Development Fostering High Order Thinking Skills on Physics Learning," in International Conference on Education, Business and Management (ICEBM-2017), 2017, no. January, pp. 102-107.

[11] a. Afandi, S. Sajidan, M. Akhyar, and N. Suryani, "Pre-service science teachers perception about high order thinking skills (HOTs) in 21st century," Int. J. Pedagog. Teach. Educ., vol. 2, no. 1, pp. 301-308, 2018.

[12] B. Tanujaya, J. Mumu, and G. Margono, "The Relationship between Higher Order Thinking Skills and Academic Performance of Student in Mathematics Instruction," Int. Educ. Stud., vol. 10, no. 11, p. 78, 2017.

[13] W. M. Al Rabadi and R. K. Salem, "The Level of High-Order Thinking and Its Relation to Quality of Life among Students at Ajloun University College," Int. Educ. Stud., vol. 11, no. 6, p. 8, 2018.

[14] B. Tanujaya, "Development of an Instrument to Measure Higher Order Thinking Skills in Senior High School Mathematics Instruction,” J. Educ. Pract., vol. 7, no. 21, pp. 144-148, 2016.

[15] Y. M. Heong et al., "The Level of Marzano Higher Order Thinking Skills among Technical Education Students," Int. J. Soc. Sci. Humanit., vol. 1, no. 2, pp. 121-125, 2011.

[16] I. W. Agustina and S. M. Amin, "Profil pengajuan soal matematika siswa kelas vii smp pada materi perbandingan ditinjau dari perbedaan kemampuan matematika dan perbedaan jenis kelamin," MATHEdunesa, vol. 2, no. 2, pp. 1-8, 2013.

[17] A. Rahman, "Pengajuan Masalah Matematika Ditinjau dari Gaya Kognitif dan Kategori Informasi," J. Ilmu Pendidik., vol. 19, no. 1, pp. 244-251, 2013.

[18] D. N. Fakhomah and M. S. Utami, "Pre-Service English Teacher Perception About Higher Order Thinking Skills (HOTS) in the 21st Century Learning," Int. J. Indones. Educ. Teach., vol. 3, no. 1, pp. 41-49, 2019.

[19] C. Stuart and D. Thurlow, "from the SAGE Social Science Collections . Rights Reserved .," Ann. Am. Acad. Pol. Soc. Sci., vol. 503, no. 1, pp. 122-136, 1993.

[20] T. Hashim, N. M. Noh, and N. Abdullah, "Teachers' Perception on Higher Order Thinking Skills as an Innovation and its Implementation in History Teaching," Aust. J. Basic Appl. Sci., no. August 2016, pp. 215-221, 2015. 